УДК $903.2(477.73)$ «632.5»

DOI: https://doi.org/10.33782/eminak2020.1(29).383

\title{
ЗООМОРФНЫЕ ИЗОБРАЖЕНИЯ В ПОЗДНЕМ ПАЛЕОЛИТЕ СТЕПНОГО ПОБУЖЬЯ (НА ПРИМЕРЕ ПОСЕЛЕНИЯ АНЕТОВКА 2)
}

\author{
Алла Главенчук \\ Одесский археологический музей НАН Украины (г. Одесса, Украина) \\ e-mail: glavenchuk@gmail.com \\ ORCID: https://orcid.org/0000-0002-2111-5398
}

На пізньопалеолітичному поселенні Анетівка 2 зібрана багата колекція мобільної скульптури й інших предметів неутилітарного призначення, що ілюструють духовне життя первісного населення прильодовикового степу в Гранітно-степовому Побужжі 18-19 тисяч років тому. Зооморфна скульптура малих форм на Анетівка 2 представлена досить масово. Серед них скульптури бізонів, мамонтів, зайців, птахів, представників сімейства котячих, коня, носорога і зооморфні фігурки, за якими складно визначити, яку тварину зображено. Зооморфні фігурки виготовлені зі щільних глинистих стяжінь, каоліну, вохри, квариу, алювіальних гальок, пісковиків, пісковикового кварциту, талькового сланцю та кістки.

Ключові слова: Північно-Західне Причорномор'я, пізній палеоліт, Анетівка 2, зооморфні зображення, скульптура малих форм

Позднепалеолитический памятник Анетовка 2 с эпиграветтским технокомплексом функционировал в степном Побужье в период максимума последнего оледенения (возраст памятника - 18-19 тыс. лет). Поселение находится на мысу высокого правого берега реки Бакшалы - притока Южного Буга. Раскопки Анетовки 2 ведутся с 1978 г. За это время раскопано около 2000 м² площади памятника, найдено около 2 млн. кремневых изделий и 0,5 млн. фрагментов костей животных ${ }^{1}$. Анетовка 2 характеризуется особенной массовостью археологических материалов.

С 1992 по 2017 год основные работы велись на северо-восточном производственном участке ЕП/13-22 (100 м²) и ИП/23-30 (54 м²)2, который является частью одного из трех, выделенных В.Н. Станко на Анетовке 2, производственных комплек$\mathrm{COB}^{3}$.

\footnotetext{
${ }^{1}$ Станко В.Н., Григорьева Г.В., Швайко Т.Н. Позднепалеолитическое поселение Анетовка 2. Киев, 1989. 138 с.; Станко В.Н. Охотники на бизона в позднем палеолите Украины // Археологический альманах. № 5. Донецк, 1996. С. 129-138.

2 Главенчук А.В. Раскопки производственного участка на Анетовке 2 // Археология и этнология Восточной Европы: материалы и исследования. Одесса, 1997. С. 76-86; Главенчук А.В. Исследование производственного участка на позднепалеолитическом поселении Анетовка 2 // Stratum plus. 2003-2004. № 1. С. 206-227; Главенчук А.В. Производственный участок на позднепалеолитическом поселении Анетовка 2 // Археологические записки. Ростов-на-Дону, 2003. Вып. 3. С. 51-58; Главенчук А.В. Планиграфия находок и микростратиграфия культурного слоя участка ЕИ/13-22 на поселении Анетовка 2 // Stratum plus. 2005-2009. № 1. С. 225-242; Главенчук А. Методика изучения открытых степных памятников позднего палеолита с «взвешенным» культурным слоем на примере Анетовки 2 (1992-2017 гг.) // Емінак. 2018. 3 (23). Т. 3. С. 21-34.

3 Станко В.Н. Охотники на бизона... С. 131; Станко В.Н. Некоторые итоги изучения позднего палеолита Северо-Западного Причерноморья (Южнобугская группа памятников) // Археология и этнология Восточной Европы: материалы и исследования. Одесса, 1997. С. 25.
} 
Археологические находки на поселении представляют собой, в первую очередь, минеральное сырье и изделия из него. Обнаружен и ряд материалов органического происхождения ${ }^{4}$

Основным каменным сырьем на Анетовке 2 служил кремень, но, кроме него, древние жители использовали более десятка других минералов и горных пород5.

Для Анетовки 2, как и для многих степных памятников характерно залегание находок в т.н. «взвешенном» культурном слое. Работа с подобным слоем имеет свою специфику. С 1992 г. методика раскопок включает обязательную «сплошную» промывку культурного слоя, которая позволяет исключить потери артефактного материала. Благодаря подобной методике исследования, появились находки, раньше вообще не присутствующие в описи предметов Анетовки 2, очень часто - удивительной сохранности, не характерной для степных памятников: древние ракушки, мелкие бусинки, подвески, предметы первобытного мобильного искусства. Для большинства таких находок периода палеолита типичны весьма маленькие размеры. Внимательное отношение ко всем без исключения находкам, происходящим с культурного слоя Анетовки 2, применение обязательной «сплошной» промывки культурного слоя привело к открытию первобытного искусства в степной зоне, в Гранитно-степном Побужье.

На поселении Анетовка 2 найдены следующие неутилитарные предметы: украшения (подвески, бусинки, бисеринки); скульптура малых форм (мобильная скульптура); предметы с гравировкой, нанесенными узорами, выемками, прорезями, знаками, рисунками (кость, камни). Таких предметов неутилитарного назначения на поселении обнаружено несколько сотен.

Предметы первобытного искусства, обнаруженные на памятнике, включают и скульптуру малых форм (предметы мобильного искусства), представленные геометрическими формами (например, диски, треугольники), антропоморфными и зооморфными изображениями. Антропоморфьые изображения на памятнике представлены скульптурами из разных пород камня (твердого и мягкого) и кости, найденные в целом или фрагментированном виде. Они изображают человека полностью (фигуру) или только голову (лицо) антропоморфа. Исполнены они с помощью разных приемов: гравировка, резьба, пришлифовка, сверление, выбивание, вырезание, «выемка» зерен кварца для изображения глаз и рта. Использовались для изготовления скульптур камни как мягких, так и твердых пород: песчаник, глинистые стяжения, каолин, жильный кварц.

Зооморфная скульптура малых форм на Анетовке 2 представлена достаточно массово. Подобных изделий найдено намного больше, чем антропоморфных изображений. Для настоящей работы нами было обработано 106 зооморфных фигурок. Среди них - скульптуры бизонов (напр.: рис. 5.1; 1.2), мамонтов (напр.: рис. 2.1; 2.2; $3.1 ; 3.2 ; 4.1 ; 4.2 ; 4.3$ ), зайцев (напр., рис. 1.1; 5.4), птиц, представителей семейства кошачьих (напр., рис. 5.2; 5.3), лошади, носорога и зооморфные фигурки, по которым сложно определить, какое животное изображено (табл. 1). Зооморфные фигурки

\footnotetext{
4 Главенчук А.В. Материалы органического происхождения на позднепалеолитическом поселении Анетовка 2 в степном Побужье // Человек в истории и культуре. Вып. 3. Одесса, 2017. С. 139145.

5 Главенчук А.В. Использование минерального сырья на позднепалеолитическом поселении Анетовка 2 // Материалы по археологии Северного Причерноморья. Вып. 13. Одесса, 2015. С. 133-146.
} 
изготовлены из плотных глинистых стяжений, каолина, охры, кварца, аллювиальных галек, песчаников, песчаникового кварцита, талькового сланца и кости. Древние мастера Анетовки 2 в качестве сырья для изготовления зооморфных мобильных скульптур, так же как и для изготовления антропоморфных, использовали как твердые материалы, так и мягкие.

Животных изображали как полностью, «в полный рост» (89 экз.) (напр., рис. 1-4; 5.1; 5.4), так и «часть вместо целого» - только голову какого-либо животного (17 экз.) (напр., рис. 5.2; 5.3). Большинство фигурок найдены целыми (иногда - с небольшими повреждениями, не влияющими на общее впечатление) (102 экз.), некоторые - во фрагментированном виде (4 экз.). В некоторых случаях складывается впечатление о намеренном нанесении повреждений на отдельные фигурки. Единичные поделки были изготовлены (или предпринималась такая попытка) в виде подвесок.

Двойные изображения животных («перевертыши»). На памятнике найдены несколько изделий (6 экз.), которые являются двойными изображениями животных:

1) изображение двух одинаковых или разных животных с разных концов заготовки (верх-низ) - когда животные повернуты друг к другу ногами (рис. 2.1; 2.2.);

2) изображение двух разных животных на разных сторонах заготовки («аверсреверс» (лицевая и обратная));

3) изображение с одной стороны заготовки одинаковых или разных животных (голов на одном «туловище»), когда головы животных «смотрят» в разные стороны (с разных боков на одной стороне).

Технология изготовления зооморфной скульптуры малых форм. Для изготовления скульптуры малых форм палеолитическими жителями Анетовки 2 использовались кремневые резцы и пластины. Для работы с твердым и мягким материалом мастерами Анетовки 2 применялись следующие технологические приемы: нанесение небольших сколов, резание, пиление, пикетаж, сверление, выбивание зерен (в кварце), оббивка, шлифовка, заглаживание. Некоторые фигурки изготовлены в виде барельефа в сочетании с гравировкой и резьбой. Приемы обработки минерального материала с целью изготовления той или иной поделки часто сочетались между собой.

Для изготовления скульптуры мастера Анетовки 2 брали подходящую заготовку (гальку, камень) в готовом виде, иногда используя уже похожий на какое-либо животное камень, чтобы впоследствии, минимально подправив его, получить желаемое изображение. Если готовой подходящей заготовки не было, мастер подготавливал ее: отбивал нужного размера куски, фрагменты, отрезал/отпиливал нужной формы и размера заготовку (например, в глинистых стяжениях) и «вписывал» в него изображение зверя. Часто форма заготовки «диктовала» форму туловища изображаемого животного (удлиненная фигура по горизонтали и короткая по вертикали, или высокая и узкая фигура). Разделительные линии (линию, отделяющую хобот от головы у мамонта, линию, отделяющие голову от шеи) изображали как прорезанием, гравировкой (прочерчиванием), так и высверливанием, пикетажем, нанесением выемок, располагающихся в линию. Иногда эти приемы комбинировались. Некоторые находки зооморфов на производственном участке Анетовки 2 свидетельствуют о том, что они были изготовлены здесь и остались на месте изготовления. Об этом 
говорит тот факт, что здесь рядом были найдены и сами готовые поделки и кусочки минерала, которые были отрезанные от заготовки во время изготовления фигурки.

Характеристика материалов для изготовления зооморфной скульптуры малых форм. Для изготовления зооморфных поделок использовали как мягкие, так и твердые минералы и породы камня (табл. 2). Эти минералы, используемые в качестве сырья для изготовления мобильных скульптур, в большинстве своем являлись сырьем массовым и часто легкодоступным для палеолитических обитателей Анетовки 2.

На первом месте по частоте использования минералов в качестве сырья для изготовления зооморфных скульптур на Анетовке 2 находятся различные плотные глинистые стяжения, включая каолин (41 экз.) - мягкий, пластичный, податливый материал. На втором месте находится жильный кварц (38 экз.), являющийся довольно твердым минералом (7 из 10 баллов по шкале Мооса), для обработки которого необходимо было прикладывать определенные усилия и обладать умением и навыками. Это - два разных материала, на равных применяемых в качестве заготовок для мелкой пластики на Анетовке 2. Цвет зооморфных поделок зависит от цвета использованного минерала: белый, оттенки желтых и палевых, оттенки природных охристых пигментов, коричневый, серый.

Плотные глинистые стяжения. Глинистые породы - уплотненные (связные) скопления мельчайших частиц разрушенных пород («породной муки»), состоящие преимущественно из глинистых минералов. Главные их представители - каолин, глина, суглинок, мергель, сланцеватая глина и лесс 6.

Глинистые породы были легкодоступны для первобытных обитателей Побужья, легко обрабатывались, пластичны. В Побужье (в том числе, и в непосредственной близости от памятника, буквально, «под ногами»), присутствуют глинистые породы на любой вкус и выбор. Анетовцы широко использовали их в качестве поделочного материала, источника красок (белых, желтоватых и охристых цветов). В каждом скоплении северо-восточного производственного участка обычно присутствуют несколько кусков охры и 1-2 куска каолина или мергеля (как запас красок, или заготовки для поделок?). Мы особо не выделяли глинистые стяжения, найденные на раскопе, не имеющие специальной обработки, так как сложно определить находятся ли эти стяжения здесь в качестве естественных включений лессовидного суглинка, в котором залегал культурный слой, или в качестве принесенных сюда первобытными людьми манупортов, не использованных в дальнейшей деятельности. Поэтому, посчитать запас глинистых заготовок для первобытных поделок не представляется возможным, так как глинистые стяжения «добывались» и непосредственно возле поселения.

Каолин, как материал для изготовления поделок, - сырье довольно хорошего качества. И на сегодняшний день в Степном Побужье, включая ближайшие окрестности с.Анетовка, легко можно найти выходы каолина. Чистый каолинит - снежнобелого цвета, в смесях с кварцем и полевыми шпатами бывает сероватожелтоватым. Каолин - довольно мягкий материал (твердость 2-2,5 единиц по шкале $\left.\mathrm{Mooca}^{7}\right)$, легко поддается обработке и легко растирается в порошок.

\footnotetext{
6 Шуман В. Мир камня. Т. 1. Горные породы и минералы. Москва, 1986. С. 36, 100.

7 Ibid. C. 197.
} 
На Анетовке 2, в начале 90-хгг. ХХ в., было зафиксировано и изучено В.Ф. Петрунем большое, мощное каолиновое пятно (округлой формы, до 5 м диаметром), расположенное недалеко от производственных участков ЕП/13-22, ЕС/9-12. Пятно имеет искусственное происхождение, грунт интенсивно прокрашен каолином на несколько сантиметров. Мощность пятна была такова, что, несмотря на осуществленную прокопку под культурным слоем на 20 см, и сегодня (по прошествии почти 30 лет с момента его нахождения), остатки пятна просматриваются на памятнике. Здесь же собраны куски каолина разных размеров. Мы предположили, что не только мощность, но и относительно правильная форма каолинового пятна обусловлена тем, что действия, связанные с использованием каолина (раскраска ли тел людей, обработка шкур, прочие) происходили неоднократно и внутри помещения типа шатрового дома округлой формы (диаметр многих известных первобытных построек составляет 4-8 м).8 Кроме материала для поделок и украшений (бусинок и подвесок), каолин мог служить первобытным жителям Анетовки 2 в качестве источника природной белой краски, минеральных карандашей и «портняжных» мелков, средства для защиты от гнуса, ранозаживляющего средства, первобытного «дезодоранта»9. Из каолина изготовлено 10 зооморфных скульптур (напр.: рис 1.2), из других глинистых стяжений - 31 (напр.: рис $2.1 ; 2.2 ; 3.1 ; 3.2 ; 4.3 ; 5.1 ; 5.2 ; 5.3$ ).

охристые породы (пигментные охры). На Анетовке 2 зафиксировано широкое использование пигментных охр в виде минерального сырья, окрашенных участков грунта, украшений (бусинки, подвески) и поделок из охристых минералов, «минеральных карандашей», окрашенных черепов и лопаток бизонов, орудий труда для изготовления кремневых изделий (отбойники, наковальни). Охристое сырье на стоянке Анетовка 2 использовали как без дополнительного обжига, так и предварительно обожженное.

Твердость этих минералов составляет от 1,0 до 6,5 по шкале Мооса, так что в разных случаях охристое сырье может выступать как в виде твердых, так и в виде мягких пород камня. Охра была важным сырьем для изготовления поделок и украшений. Зооморфных скульптур, изготовленных из охры - 7 экз. (напр.: рис. 4.1; 5.4). Необходимо отметить хорошую сохранность поделок из охры, несмотря на то, что минимальная твердость охры составляет 1,0 ед. Но заизвесткованность многих хрупких или мягких изделий, происходящих из культурного шара Анетовки 2, позволила в свое время «законсервировать» и «укрепить» эти предметы и сохранить их до сегодняшнего дня.

Источники охристых красителей Анетовки 2: лимониты (твердость 1-5 ед. по шкале Мооса), гематиты (6,0-6,5 ед. по шкале Мооса), магнетиты, железистые роговики-микрокварциты, включая джеспилиты, глинистые породы подходящего цвета, заохренные (ожелезненные) каолиновые стяжения и заохренные кварцевые гальки, местные песчаники красного или близкого к красному цвета, землистые формы охр. Происхождение этих источников красок, определенное В.Ф.Петрунем, С.В. Кадуриным и И.А. Лосевым - как удаленное, так и местное: район Криворожско-

\footnotetext{
8 Главенчук А.В. К вопросу об использовании красок в позднем палеолите (на примере позднепалеолитической стоянки Анетовка 2) // Человек в истории и культуре. Вып. 2. Одесса, 2012. С. 193200.

9 Ibidem.
} 
го железорудного бассейна, окрестности р. Синюхи, Побужье, в т.ч. - территория памятника (землистые формы охр) и ее ближайшие окрестности ${ }^{10}$.

Кварц жильный. Для поселения Анетовка 2 характерно наличие огромного количества кварца в виде артефактов и манупортов, упорная обработка кварца, который является довольно твердым материалом (при наличии легкодоступного массового мягкого материала, легко поддающегося обработке, такого как глинистые стяжения). Кварц находится на втором месте (после различных глинистых стяжений) по количеству изготовленных из него зооморфных фигурок (38 экз.) (напр.: рис. 4.2).

Первобытные жители Анетовки 2 много и интенсивно использовали разные кварцы. Это является определенным феноменом памятника, так как обработка кварца - довольно трудоемкая и требующая больших затрат силы и времени в условиях каменного века (твердость кварца такая же, как и у кремня - 7 единиц по шкале Мооса). Численность кварцевых артефактов и манупортов на Анетовке 2 исчисляется тысячами.

Кварцевые породы камня на поселении представлены горным хрусталем, дымчатым кварцем, морионом, розовым кварцем, цитрином, жильным кварцем. Есть окатанные мелкие кварцевые гальки, явно аллювиального происхождения. Судя по количеству и разнообразию кварцевого сырья, оно очень привлекало первобытных поселенцев Анетовки 2 своими качествами. Представление об использовании кварцевых пород на стоянке дают находки в виде манупортного минерального сырья, орудий, украшений и поделок из кварца, орудий для изготовления кремневых изделий (отбойники, ретушеры), растиральников для краски, а также - множественных осколков и обломков различных кварцев. В.Ф. Петрунь определил несколько источников происхождения подобного сырья, как существенно удаленных от Анетовки, (кварцы, характерные для месторождений Криворожья, Новоукраинского массива Ингуло-Ингулецкого региона, месторождения в Старо-Бешевскогм районе Донецкой области) так и относительно близких к ней (из кристаллических пород Украинского щита, обнажающихся где-то не слишком далеко от памятника) ${ }^{11}$.

Жильный кварц местного происхождения (Побужье) представлен в виде отдельностей (выломов), желваков и окатанных галек. Кварц, найденный во время раскопок Анетовки 2, представлен как крупно-, так и мелкоформатными находками. Жильный кварц во множестве использовали в качестве отбойников, ретушеров, сырья для изготовления орудий, материала для изготовления поделок и украшений.

Во время раскопок позднепалеолитической стоянки Анетовка 13 в 1993 г. было выяснено, что охотники из Анетовки 13 (которая находится в 4-5 км от Анетовки 2), располагались на скале из жильного кварца, которая частично была вскрыта раскопками. Так что, подобное сырье в палеолите в Степном Побужье было легкодоступным. И сегодня в окрестностях впадения Бакшалы в Южный Буг можно встретить в большом количестве кварцевые камни ${ }^{12}$.

\footnotetext{
10 Петрунь В.Ф. О мелкоформатном, преимущественно некремнистом камне из промывок культурного слоя поселения Анетовка 2 на реке Бакшала // Археологические записки. Вып. 3. Ростовна-Дону, 2003. С. 59-67; Главенчук А.В. Использование пигментных охр на позднепалеолитическом поселении Анетовка 2 // Stratum plus. 2012. № 1. С. 293-300; Главенчук А.В. Пігментна вохра за даними досліджень пізньопалеолітичного поселення Анетівка 2 // Кам'яна доба України. Вип. 17-18. Київ, 2017. С. 144-152.

11 Петрунь В.Ф. О мелкоформатном, преимущественно некремнистом камне... С. 62-63.

12 Главенчук А. Использование кварцевых пород камня на позднепалеолитическом поселении Анетовка 2 // Древнее Причерноморье. Вып. 10. Одесса, 2013. С. 155-161.
} 
В некоторых случаях зооморфные фигурки Анетовки 2, изготовленные из кварца заохрены в отдельных местах. Ранее мы предполагали, что охру могли использовать как абразив, который увеличивал трение при пилении и сверлении. Но проведенные эксперименты летом 2019 г. по сверлению кварца на базе Анетовской экспедиции (Роман Галкин) ${ }^{13}$ показали, что охра затрудняет сверление. Возможно, охра в данном случае использовалась в магических или ритуальных целях, или просто обозначала что-то (акцентировала внимание), или усиливала впечатление того, кто видел эти фигурки. Для этого применялось обозначение цветом - например, заохренные точки-пикетаж. Возможно, красная краска применялась с целью усиления цветом эффекта от восприятия изделия (изображалось раненное животное?). Хотя в некоторых случаях заохренность в месте пиления или сверления отверстия могла обозначать хорошо видимую наметку, нанесенную красной краской, для облегчения более точного исполнения нужной производственной операции.

Большая коллекция кварцевых предметов, собранная при раскопках Анетовки 2 придает определенное своеобразие поселению. Использование кварца как поделочного камня для изготовления украшений и предметов мобильного искусства в большом количестве является отличительной характерной чертой Анетовки 2 (в сравнении с другими памятниками позднего палеолита, на которых найдены предметы первобытного искусства). По-видимому, это связано с легкой доступностью, многочисленностью, хорошим качеством и внешней привлекательностью этого сырья.

Аллювиальные кремневые гальки (твердость 7 из 10 баллов по шкале Мооса). На поселении в большом количестве присутствуют, как в виде артефактов, так и в виде манупортов, аллювиальные кремневые гальки типа карпатской (и мелкоформатные, и более крупные), вне сомнения, специально принесенные на памятник для дальнейшего использования. Кремневые аллювиальные гальки разных цветов иногда использовались в качестве поделочного материала для изготовления украшений и статуэток на Анетовке 2. Из аллювиальных кремневых галек изготовлено 5 зооморфных поделок.

Песчаники. Песчаник - наиболее широко распространенная осадочная горная порода, обычно отчетливо слоистая. Образуется путем цементации зерен песка глиной или кремнем. В составе песчаника преобладает кварц. Технические характеристики песчаников зависят от типа цемента и его количественных соотношений с песчинками, а также от формы и распределения пор ${ }^{14}$

Песчаник - часто довольно мягкий и легко поддающийся обработке камень, который использовали для изготовления статуэток. Песчаники Анетовки 2 - местное, легкодоступное сырье, происходящее из территории Гранитно-степного Побужья, которые люди могли получать, не прикладывая особых усилий по их поиску и добыче. В Побужье широко распространены песчаники, которые на стоянке использовались, в первую очередь, как отбойники, ретушеры, абразивы, наковальни, подставки для разделки туш животных. Также песчаники применялись для изготовления разных поделок, Из песчаника изготовлены 12 предметов, относящихся к зооморфной мобильной скульптуре.

По одной зооморфной скульптуре изготовлено из песчаникового кварцита, та-

\footnotetext{
${ }^{13}$ См. статью Р. Галкина в настоящем номере журнала «Емінак»: Галкін Р. Свердління кварцу за даними експерименту...

14 Шуман В. Указ. соч. С. 108.
} 
лькового сланца и кости. Но даже единичные находки свидетельствуют, что с этими материалами работали, их использовали (т. к., естественно, найдены далеко не все поделки).

Песчаниковые кварциты (или кварцитовые песчаники), среди археологов часто именуемые кварцитами, по мнению В.Ф. Петруня, в основном - местного происхождения. Кварцитовые песчаники - очень крепкие и прочные, они относятся к твердым породам камня. В Степном Побужье они широко распространены. Часто эта осадочная порода залегает вместе с кремнем (в одном желваке). Нами найдено сырье, нуклеусы и изделия, частично состоящие из кремня, частично - из песчаникового кварцита, или кварцитового песчаника (по В.Ф. Петруню: в зависимости от преобладания минералов в составе). Этот материал тоже часто использовали на памятнике для изготовления орудий (аналогично кремню), в качестве плитокнаковален, отбойников, ретушеров, для изготовления поделок.

тальковые сланцы (твердость от 1 до 3-4). Тальковые сланцы - это мягкий, но хрупкий и слоистый материал. На памятнике найдены больше сотни маленьких кусочков тальковых сланцев. В.Ф. Петрунь изучивший 49 обломочков таких сланцев, выделил среди них северокавказский серпентинит, хлорито-актинолитовые и талько-хлорито-актинолитовые сланцы как Приазовья, так и Криворожья ${ }^{15}$. Необходимо указать, что все находки представлены в довольно маленьких кусочках, т.е. сырье, принесенное издалека, в данном случае старались использовать помаксимуму16. На некоторых крупных фрагментах тальковых сланцев сохранились признаки утилизации, два из которых были подробно описаны В.Ф. Петрунем, который выдвинул предположения о возможных вариантах их использования 17.

Нам неизвестно о случаях массового использования тальков в палеолите. Для палеолита известны находки маленьких скульптурных фигурок из тальковых пород, представляющих предметы мобильного искусства. На Анетовке 2 найдена только одна зооморфная скульптура из талька (фигурка сидящего зайца).

Кость. Кость является доступным, удобным, относительно мягким, обладающим небольшой твердостью, и пластичным материалом, пригодным для изготовления различных поделок.

На памятнике найдено близко 0,5 млн. фрагментов костей животных. Среди фаунистических остатков около 98\% всех костных определимых остатков составляют кости бизона ${ }^{18}$. Кость и рог на Анетовке 2 использовали в качестве сырья для изготовления различных орудий, инструментов, поделок. На памятнике найдено более 800 изделий из кости и рога северного оленя. Из рогов изготовляли наконечники, стрелки, лощила, лопаточки. Из кости бизона, которая являлась массовым сырьем на памятнике (т. к. бизон был основным объектом охоты), изготовлены наконечники, стрелки, лощила, острия, лопаточки, колышки, из ребер вырезались пластины, использование которых на сегодняшний день не совсем понятно, бусинки, поделки. Найдены кусочки костяных изделий с нанесенным на них орнаментом, гравиров-

\footnotetext{
15 Петрунь В.Ф. 0 мелкоформатном, преимущественно некремнистом камне... С. 63-65.

16 Главенчук А.В. Применение тальковых сланцев на позднепалеолитическом поселении Анетовка 2 // Научная международная конференция «Биоархеологические и этнокультурные исследования в юго-восточной Европе». Crichana Veche (Cahul), 14-16 august 2018. C. 15-17.

17 Петрунь В.Ф. О мелкоформатном, преимущественно некремнистом камне... С. 64, 66.

18 Бибикова В.И., Старкин А.В. Характеристика остеологического материала из раскопок позднепалеолитического поселения Анетовка 2 / Станко В.Н., Григорьева Г.В., Швайко Т.Н. Позднепалеолитическое поселение Анетовка 2. Киев, 1989. С. 127-131.
} 
кой. Из зубов животных изготовлены подвески и бусинки. Учитывая не очень хорошую сохранность кости, очевидно, что подобных изделий было намного больше, чем нам известно сегодня. Из кости изготовлены две статуэтки: антропоморфная поделка (фигурка женщины) из ребра крупного животного (бизона?) и фигурка бегущего зайца (рис. 1.1) из толстой стенки трубчатой кости крупного животного (бизона?) (определение Е.П. Секерской).

Экспериментальная обработка кварца (твердый материал) и каолина (мягкий материал) кремневыми орудиями. Многочисленные скульптуры, изготовленные из кварца, заставили задуматься, чем палеолитические жители Анетовки 2 , в распоряжении которых из твердых минеральных пород были только кремень и, собственно, кварц, обрабатывали кварц? Возможно ли обработать кварц кремнем, если они одной твердости по шкале Мооса?

Нам известно использование кварца на Анетовке 2 в качестве отбойников и ретушеров, которые использовали для обработки кремня. Но вырезание поделок из кварца, просверливание бусин из кварца - более тонкая работа, чем расщепление кремня и ретуширование изделий. В 2013 г. на базе Анетовской палеолитической экспедиции были проведены эксперименты по изготовлению небольших зооморфных скульптур из твердых и мягких минералов (кварца и каолина). Для эксперимента были использованы минералы местного происхождения (жильный кварц и каолин), собранные нами в Гранитном Побужье. Участники - студенты-практиканты 1 курса. Ставились задачи: изготовить поделки из кварца и каолина кремневыми пластинами и резцами и получить эталонные кремневые орудия со следами работы по кварцу и каолину.

Изготовление скульптур мамонта из кварца и каолина. Статуэтки мамонта были изготовлены одним и тем же студентом (возраст - 18 лет), обладающим определенными навыками (закончил художественную школу), но не имеющего опыта резьбы по камню. Эксперимент показал, что обладая определенными знаниями и навыками, но, не имея опыта вырезания фигурок из определенного материала, можно изготовить фигурку мамонта из каолина, тщательно прорабатывая детали, затратив при этом от 20 минут чистого времени работы. Изготовление фигурки мамонта из жильного кварца, идентичного использованному на Анетовке 2, заняло примерно 1 час чистого времени работы. В результате этого эксперимента выяснилось, что кварц можно обрабатывать кремнем, имеющим такую же твердость (резцом, или углом сломанной кремневой пластины).

Экспериментальное изготовление поделок из каолина (мягкий материал) кремневой пластиной (угол сломанной пластины). Зооморфные фигурки в этом случае изготовлялись несколькими девушками (возраст - 18 лет). Задачей ставилось изготовление зооморфной фигурки (вырезание любого животного, по желанию). Для эксперимента использован каолин хорошего качества (куски и окатанные плотные «гальки», взятые из р. Южный Буг). Каждая девушка вырезала из каолина небольшую скульптуру животного, затратив при этом на изготовление тщательно проработанных фигурок от 15 до 80 минут чистого времени. Время, затраченное на изготовление одной фигурки, зависело от тщательности проработки, темперамента и характера изготовителя. Эксперимент показал, что схематичную фигурку животного из мягкого материала мастер, имеющий определенные навыки, мог изготовить буквально за несколько минут. Чем тщательнее проработка изделия, тем больше времени на это затрачено. 
Изображения животных. Древние охотники были весьма наблюдательны, так как от этого зависела их жизнь и благополучие. Изготавливая скульптуры животных, они изображали самые характерные визуальные признаки, по которым легко можно узнать животное: мощную голову, шею, горб, иногда - рога, шейную складку у бизона; хобот и массивную голову у мамонта; клюв у птицы; уши у кошачьих; уши и выгнутую спину у зайца. У разных животных часто изображали глаза, характерные морды, уши, иногда - ноздри. Большинство изображаемых животных определяется легко и безошибочно. Одни скульптуры - более схематичны, другие - тщательно проработанные. По-видимому, тщательность изображения зависела от способностей, умения и опыта мастера и сколько времени он мог выделить на изготовление фигурки.

Животные изображены преимущественно в спокойном состоянии: стоящие, пасущиеся, иногда - лежащие/спящие (бизоны), сидящие (зайцы), иногда изображались животные в движении: нападающие/атакующие животные (бизоны), бегущие (заяц) (рис. 1.1).

Все фигурки - небольших размеров. Они легко помещаются на ладони, все их удобно переносить. Их размеры варьируются от 6 мм до 60 мм. Фигурки есть как объемные, так и уплощенные. Изображения наносились и с обеих сторон заготовки, и - только с одной (большинство из односторонних изображений «смотрят» влево). Почти все фигурки можно было поставить на плоскость без дополнительной опоры (для этого подрезался низ фигурки, чтобы подготовить плоскую площадку в основании скульптуры). Возможно, это свидетельствует, что подобные изделия выставлялись в жилище в определенном (специально выделенном для этого?) месте.

Находки зооморфных скульптур Анетовки 2 в основном связаны со скоплениями - рабочими местами. 92 зооморфных скульптуры имеют точную привязку, 14 фигурок - без точной привязки. Планиграфически часто они концентрируются по несколько штук на квадрате. Некоторые, по-видимому, лежали в ямках, хотя сами ямки во взвешенном культурном слое не зафиксированы. О подобном нахождении косвенно свидетельствует толстый известковый налет на обратной стороне статуэтки - на той стороне, на которой она лежала (внизу ямки). Это может свидетельствовать о том, что эти скульптуры могли быть связаны с какими-то ритуалами, производившимися с определенной целью, в результате которых фигурки были положены в ямки и спрятаны или захоронены. В нескольких случаях мы наблюдаем попытки изготовить фигурки-подвески. В одном случае - это фигурка мамонта, подвешиваемого вниз головой.

Скульптуры мамонтов и скульптуры бизонов. Наличие скульптур бизонов на Анетовке 2, где к тому же обнаружен ритуальный комплекс, связанный с культом бизона ${ }^{19}$, воспринимается, как само собой разумеющееся. А вот обнаружение многочисленных изображений мамонта на стоянке охотников на бизона, который являлся главным объектом охоты на Анетовке $2^{20}$, может вызывать различные вопросы и предположения о людях, их изготовивших. Количественно фигурки мамонтов - самые многочисленные, они в три раза превышают число фигурок бизона. Почему?

${ }_{19}$ Станко В.Н. О культе быка в раннепервобытных общинах степного Причерноморья // Древнее Причерноморье. Одесса: ОАО, 1993. С. 3-6; Станко В.Н. Охотники на бизона в позднем палеолите Украины... С. 129-138; Станко В.Н. Анетовка 2 - позднепалеолитическое поселение и святилище охотников на бизонов в Северном Причерноморье // Stratum plus. 1999. № 1. С. 322-325.

20 Бибикова В.И., Старкин А.В. Характеристика остеологического материала... С. 127-131. 
Фигурки мамонтов и бизонов изготавливали представители разных групп охотников, приходивших на мыс в разное время; или они изготовлены одними и теми же людьми относительно одновременно? Мамонт был тотемом группы охотников на бизонов? Видели ли воочию палеолитические охотники, обитавшие здесь, мамонта? Так как в списке остеологических остатков Анетовки 2 костей мамонта нет, есть единственный фрагмент пластинки зуба мамонта, но мы его относим к материалам первобытного собирательства различных материалов (вместе с зубом третичной акулы, панцирем ископаемой черепахи, зубом медведя и т.п.) 21 , а не результатам охоты.

Довольно большое количество фигурок мамонтов, при изготовлении которых мастерски делался акцент на главных визуальных признаках (массивная голова, хобот), свидетельствует, что люди, изготовившие эти предметы искусства, часто и в подробностях наблюдали за повадками этих животных (т.е., мамонты были знакомы обитателям Анетовки 2 «не понаслышке»). Учитывая мобильность первобытных коллективов и отсутствие в списке фауны костей мамонта, скорее всего мамонта, который обитал несколько севернее Анетовки, охотники на бизона в это же время видели.

Мамонт или бизон? Находки в одних и тех же скоплениях, на одних и тех же квадратах фигурок и того, и другого животного, свидетельствует о том, что изготавливали их одни и те же мастера. Особенно показательна в плане иллюстрации вышесказанного, находка на одном и том же квадрате (рядом) двух фигурок (мамонта и бизона) из железосодержащего лимонита, изготовленных из очень похожего материала, скорее всего взятого из одного месторождения. Оба предмета изображены в одном стиле - похожий «почерк» мастера (рис. 4.1; 5.4). Кроме этого, присутствуют два двойных изображения животных, так называемые «перевертыши» (когда на одной плитке или куске камня изображено двое животных), в которых присутствуют изображение и мамонта, и бизона в одной поделке-перевертыше.

Аналогии. Статуэтки животных, относящиеся к палеолитической скульптуре малых форм, прекрасно исполненные, были широко распространены в Европе и Азии на протяжении всего позднего палеолита 22 . Мобильная скульптура Анетовки 2 хорошо вписывается в мировое палеолитическое искусство. Каждое зооморфное изображение носит индивидуальный характер, несмотря на то, что все они в целом обладают общими чертами.

Наиболее близкие аналогии анетовским зооморфам мы находим на палеолитических памятниках: Сунгирь, Костенки 1, Костенки 4, Аносовка 2, Авдеево, Косоуцы.

\footnotetext{
21 Главенчук А.В. Материалы органического происхождения... С. 139-145.

22 Ефименко П.П. Костенки І. Москва-Ленинград, 1958; Абрамова З.А. Палеолитическое искусство на территории СССР. Москва-Ленинград, 1962; Leroi-Gourhan A. Préhistoire de l'art occidental. Paris, 1971; Столяр А.Д. Происхождение изобразительного искусства. Москва: Искусство, 1985. 299 с.; Борзияк И.А. Предметы изобразительной деятельности человека на многослойной стоянке Косоуцы на Среднем Днестре (Памятники древнейшего искусства на территории Молдавии). Кишинев, 1989. С.11-26; Абрамова 3.А. Роль бизона в мировоззрении палеолитического человека Европы // Stratum plus. 2001-2002 (2003). № 1. C. 171-195; Абрамова З.А. Каталог изображений мамонта в европейском палеолитическом искусстве малых форм. Stratum plus. № 1. 2003-2004 (2005). С. 23-67; Амирханов Х.А., Лев С.Ю. Произведения палеолитического искусства стоянки Зарайск А / Амирханов Х.А., Ахметгалеева Н.Б., Бужилова А.П. и др. Исследования палеолита в Зарайске. 1999-2005. Москва, 2009. С. 289-339; Яковлева Л. Найдавніше мистецтво України. Київ, 2013. С. 75-113; Верхний палеолит: образы, символы, знаки: Каталог предметов искусства малых форм и уникальных находок верхнего палеолита из археологического собрания МАЭ РАН. Ред. Хлопачев Г.А. Санкт-Петербург, 2016.
} 
В Украине аналогией скульптурам мамонта из Анетовки 2 является фигурка мамонта из мергеля из раскопок Д.Ю. Нужного, найденная на стоянке Бармакиㄹ.

Данная работа носит предварительный характер, затронувший общую характеристику зооморфной пластики, на Анетовке 2. Сложно переоценить важность обнаружения этих предметов первобытного искусства. Открытие первобытного искусства в Степной зоне Северного Причерноморья, на поселении, где пока не обнаружены жилища, закрывает хронологическую и географическую лакуну в истории палеолитического искусства. Анетовку 2 с полным правом можно внести в перечень позднепалеолитических памятников первобытного искусства. Здесь собрана богатая коллекция мобильной скульптуры и других предметов неутилитарного назначения, иллюстрирующих духовную жизнь первобытного населения приледниковой степи в Гранитно-степном Побужье 18-19 тысяч лет тому назад.

Благодарности. С огромной признательностью и благодарностью автор вспоминает Виктора Федоровича Петруня (1922-2005 гг.) - уникального специалиста, с которым мне посчастливилось сотрудничать.

Также автор выражает благодарность Наталье Борисовне Ахметгалеевой, Наталье Николаевне Скакун, Марии Николаевне Желтовой, Оксане Александровне Грицюте, Сергею Владимировичу Кадурину и Игорю Александровичу Лосеву за совместный просмотр и обсуждение предметов мобильного искусства Анетовки 2.

\section{REFERENCES}

Abramova, Z.A. (1962). Paleoliticheskoe iskusstvo na territorii SSSR [Paleolithic art in the USSR] (Svod arheologicheskih istochnikov. Arheologiia SSSR, A4-3). Moskva-Leningrad: Izdatelstvo AN SSSR [in Russian].

Abramova, Z.A. (2003). Rol bizona v mirovozzrenii paleoliticheskogo cheloveka Evropy [The Role of Bison in View of European Palaeolithic Man]. Stratum plus, 1, 171-195 [in Russian].

Abramova, Z.A. (2005). Katalog izobrazhenii mamonta v evropeiskom paleoliticheskom iskusstve malyh form [A Catalogue of Depictions of Mammoth in European Palaeolithic Miniature Art]. Stratum plus, 1, 23-67 [in Russian].

Amirhanov, H.A. \& Lev, S.Yu. (2009). Proizvedeniia paleoliticheskogo iskusstva stoianki Zaraisk A [Art Objects from Zaraisk A]. In Amirhanov, H.A., Ahmetgaleeva, N.B., Buzhilova, A.P., Burova, N.D., Lev, S.Yu. \& Mashchenko, E.N. Issledovaniia paleolita v Zaraiske. 1999-2005 (pp. 289-339). Moskva: Paleograf [in Russian].

Bibikova, V.I. \& Starkin, A.V. (1989). Harakteristika osteologicheskogo materiala iz raskopok pozdnepaleoliticheskogo poseleniia Anetovka II. [The characteristic of an osteological material from excavation of Upper Paleolithic settlement Anetovka II]. In Stanko, V.N., Grigoreva, G.V. \& Shvaiko, T.N. Pozdnepaleoliticheskoe poselenie Anetovka II (pp. 127-131). Kiev: Naukova dumka [in Russian].

Borziyak, I.A. (1989). Predmety izobrazitelnoi deiatelnosti cheloveka na mnogosloinoi stoianke Kosoucy na Srednem Dnestre [Objects of human visual activity at the multi-layered site Kosoutsy on the Middle Dniester]. In Pamiatniki drevneishego iskusstva na territorii Moldavii (pp. 11-26). Kishinev [in Russian].

Efimenko, P.P. (1958). Kostionki I [Kostionki I]. Moskva-Leningrad: Izdatelstvo AN SSSR [in Russian].

Glavenchuk, A.V. (1997). Raskopki proizvodstvennogo uchastka na Anetovke 2 [The excavation production site on Anetovka 2]. Arheologiia i etnologiia Vostochnoi Evropy: materialy i issledovaniia. (pp. 76-86). Odessa: Germes [in Russian].

Glavenchuk, A.V. (2003). Proizvodstvennyi uchastok na pozdnepaleoliticheskom poselenii Anetovka 2 [The Manufacture area of the upper Paleolithic settlement of Anetovka 2]. Arheologicheskie zapiski, (Vol. 3, pp. 51-58). Rostov-na-Donu [in Russian].

Glavenchuk, A.V. (2005). Issledovanie proizvodstvennogo uchastka na pozdnepaleoliticheskom

\footnotetext{
${ }^{23}$ Нужный Д.Ю. Верхній палеоліт Західної і Північної України (техніко-типологічна варіабельність та періодизація). Київ, 2015, Рис. 110.
} 
poselenii Anetovka 2 [Studi of a Manufacture Area on the Late Paleolithic Settlement of Anetovka 2]. Stratum plus, 1, 206-227 [in Russian].

Glavenchuk, A.V. (2009). Planigrafiya nahodok i mikrostratigrafiya kul'turnogo sloya uchastka EI/13-22 na poselenii Anetovka 2 [Spatial and micro-layer stratigraphy analysis of the Upper Palaeolithic site of Anetovka 2]. Stratum plus, 1, 225-242 [in Russian].

Glavenchuk, A.V. (2012). Ispolzovanie pigmentnyh ohr na pozdnepaleoliticheskom poselenii Anetovka 2 [The Use of Pigment Ochre at the Late Palaeolithic Site of Anetovka II]. Stratum plus, 1, 293-300 [in Russian].

Glavenchuk, A.V. (2012). K voprosu ob ispolzovanii krasok v pozdnem paleolite (na primere pozdnepaleoliticheskoi stoianki Anetovka 2) [On the use of paints in the Late Paleolithic (on the example of the Late Paleolithic site Anetovka 2)]. Chelovek v istorii i kulture. (Vol. 2, pp. 193-200). Odessa: SMIL [in Russian].

Glavenchuk, A.V. (2013). Ispolzovanie kvarcevyh porod kamnia na pozdnepaleoliticheskom poselenii Anetovka 2 [The use of quartz rock in the late Paleolithic settlement of Anetovka 2]. Drevnee Prichernomorie, 10, 155-161 [in Russian].

Glavenchuk, A.V. (2015). Ispolzovanie mineralnogo syria na pozdnepaleoliticheskom poselenii Anetovka 2 [Use of mineral at the Upper Paleolithic seite of Anetovka 2]. Materialy po arheologii Severnogo Prichernomoria, 13, 133-146 [in Russian].

Glavenchuk, A.V. (2017). Materialy organicheskogo proiskhozhdeniia na pozdnepaleoliticheskom poselenii Anetovka $2 \mathrm{v}$ stepnom Pobuzhie [Materials of organic origin in the late Paleolithic settlement of Anetovka 2 in the Steppe Bug Region]. Chelovek v istorii i kulture (Vol. 3, pp. 139-145). Odessa [in Russian].

Glavenchuk, A.V. (2018). Primenenie talkovyh slancev na pozdnepaleoliticheskom poselenii Anetovka 2 [The use of talc slates in the late Paleolithic settlement of Anetovka 2]. Abstracts of Papers: Bioarheologicheskie i etnokulturnye issledovaniia v yugo-vostochnoi Evrope. (pp. 15-17). Crichana Veche (Cahul) [in Russian].

Glavenchuk, A.V. (2018). Metodika izucheniia otkrytyh stepnyh pamiatnikov pozdnego paleolita s «vzveshennym» kulturnym sloem na primere Anetovki 2 (1992-2017 gg.) [Methods of studying Open Steppe Sites of the Upper Paleolithic with a «suspended» Cultural Layer on the Example of Anetovka 2 (1992-2017)]. Eminak, 3 (23), Vol. 3, 21-34 [in Russian].

Hlavenchuk, A.V. (2017). Pihmentna vokhra za danymy doslidzhen piznopaleolitychnoho poselennia Anetivka 2 [The pigment ochre according research on Late Paleolithic site Anetivka 2]. Kamiana doba Ukrainy, 17-18, 144-152 [in Ukrainian].

Hlopachev, G.A. (Ed.). (2016). Verhnii paleolit: obrazy, simvoly, znaki: Katalog predmetov iskusstva malyh form i unikalnyh nahodok verhnego paleolita iz arheologicheskogo sobraniia MAE RAN [Upper Paleolithic: images, symbols, signs: Catalog of objects of art of small forms and unique finds of the Upper Paleolithic from the archaeological collection of MAE RAS]. Sankt-Peterburg: Ekstraprint [in Russian].

Leroi-Gourhan André (1971). Préhistoire de l’art occidental. Paris: Mazenod.

Nuzhnyi, D.Yu. (2015). Verkhnii paleolit Zakhidnoi i Pivnichnoi Ukrainy (tekhniko-typolohichna variabelnist ta periodyzatsiia) [Upper Paleolithic of the Western and Northern Ukraine (technotypological variability and periodization)]. Kyiv [in Ukrainian].

Petrun, V.F. (2003). O melkoformatnom, preimushchestvenno nekremnistom kamne iz promyvok kulturnogo sloia poseleniia Anetovka 2 na reke Bakshala [Examination of predominantly small Stonts from the settlement of Anetovka 2]. Arheologicheskie zapiski (Vol. 3, pp. 59-67). Rostov-na-Donu [in Russian].

Petrun, V.F. (2015). Kraskovi rohovyky Tashlytskoho kompleksu ta problema zalizystykh kvartsytiv v arkheolohii [Colouring hornfels of the Tashlyck complex and the problem of ferruginous quartzite in the archaeology]. Materialy po arheologii Severnogo Prichernomoria, 13, 285-292 [in Ukrainian].

Stanko, V.N. (1993). O kulte byka v rannepervobytnyh obshchinah stepnogo Prichernomoria [About the cult of the bull in the early primitive communities of the steppe Black Sea]. Drevnee Prichernomorie. Odessa, pp. 3-6 [in Russian].

Stanko, V.N. (1996). Ohotniki na bizona v pozdnem paleolite Ukrainy [Bison hunters in the late Paleolithic of Ukraine]. Arheologicheskii almanah (Vol. 5, pp. 129-138). Doneck [in Russian].

Stanko, V.N. (1997). Nekotorye itogi izucheniia pozdnego paleolita Severo-Zapadnogo Prichernomoria (Yuzhnobugskaia gruppa pamiatnikov) [Some results of the study of the Late Paleolithic of the Northwest Black Sea Region (South Bug Monument Group)]. Arheologiia i etnologiia Vostochnoi Evropy: materialy i issledovaniia. (pp. 14-27). Odessa: Germes [in Russian]. 
Stanko, V.N. (1999). Anetovka 2 - pozdnepaleoliticheskoe poselenie i svyatilishche ohotnikov na bizonov v Severnom Prichernomor'e (Stanko V.N. Anetovka 2 - Late Palaeolithic settlement and sanctuary of hunters for bison in the Northern Black Sea region.) // Stratum plus. 1. 322-325. [in Russian].

Stanko, V.N., Grigorieva, G.V. \& Shvaiko, T.N. (1989). Pozdnepaleoliticheskoe poselenie Anetovka II [Upper Paleolithic settlement Anetovka II]. Kyiv: Naukova dumka [in Russian].

Stoliar, A.D. (1985). Proiskhozhdenie izobrazitelnogo iskusstva [Origin of art]. Moskva: Iskusstvo [in Russian].

Shuman, V. (1986). Mir kamnia. Vol. 1: Gornye porody i mineraly [The world of stone. T. 1: Rocks and minerals]. Moskva: Mir [in Russian].

Yakovleva, L. (2013). Naidavnishe mystetstvo Ukrainy [L'Art des origines en Ukraine]. Kyiv: Starodavnii svit [in Ukrainian].

\section{Alla Glavenchuk}

(The Odesa Archaeological Museum, Odesa, Ukraine)

ORCID: https://orcid.org/0000-0002-2111-5398

\section{Zoomorphic Images in the Late Paleolithic of the Steppe Buh Region (on the Example of Anetivka-2 Settlement)}

The Late Paleolithic site Anetivka-2 functioned in the steppe Buh region during the period of the Last Glacial Maximum. In addition to mass findings of flint produced items and faunal remains, the non-utilitarian objects, relating to primitive art, were found at the settlement. They include small plastic art items represented by geometric shapes, anthropomorphic, and zoomorphic sculptures.

The zoomorphic sculpture of small forms at Anetivka-2 is represented quite widely. Among them are the sculptures of bison, mammoths, hares, birds, representatives of the cat family, horses, rhinoceros, and zoomorphic figurines, which make it difficult to recognize what animal it is.

The animals are created both as a whole, and in part, for example, only the head of an animal. Most of the figurines are found intact, some in fragmented form. In some cases, one gets the impression of intentional damage to some figurines. Single items are made in the form of pendants. Several items found at the site are of a double nature when the sculptures of two animals are combined in one, in some cases, they are of the same species and sometimes different.

The prehistoric craftsmen of Anetivka-2 used both hard and soft materials as raw materials for the processing of zoomorphic mobiliary art sculptures. Zoomorphic figurines are made of leck, kaolin, ocher, quartz, alluvial pebbles, sandstones, sandstone quartzite, talc schist, and bone.

Prehistoric hunters were very observant, as their life and well-being depended on it. When making animal sculptures, they reproduce the most characteristic visual features by which one can easily recognize an animal: a massive head, neck, hump, and sometimes horns, a bison neck fold; mammoth trunk and bulky head; beak of a bird; cat's ears; ears and hogback of a hare. Different animals often have carved eyes, typical muzzles, ears, sometimes nostrils. Animals are shown mainly in a calm state, less often in motion. All figurines are not big. Their size ranges from $6 \mathrm{~mm}$ to $60 \mathrm{~mm}$. Most of the animals are recognized easily and accurately. Some sculptures are more schematic, others are carefully worked out. Apparently, the thoroughness of the sculpture depended on the abilities, skills, and experience of the craftsman and how much time he could devote to making the figurines.

Anetivka-2 has a rich assemblage of mobiliary art and other non-utilitarian objects illustrating the spiritual life of the primitive population of the mammoth steppe in the GraniteSteppe Buh region 18-19 millennia years ago.

Keywords: North-West Black Sea region, Late Paleolithic, Anetivka-2, zoomorphic images, sculpture of small forms 
Таблица 1.

Материалы для изготовления зооморфной скульптуры малых форм. Анетовка 2

\begin{tabular}{|c|l|c|c|}
\hline № п/п & \multicolumn{1}{|c|}{ Материал заготовки } & $\begin{array}{c}\text { К-во } \\
\text { изделий }\end{array}$ & $\mathbf{\%}$ \\
\hline 1 & Кварц жильный & 38 & 35,8 \\
\hline 2 & Глинистые стяжения & 31 & 29,2 \\
\hline 3 & Песчаник & 12 & 11,3 \\
\hline 4 & Каолин & 10 & 9,43 \\
\hline 5 & Охра & 7 & 6,6 \\
\hline 6 & Аллювиальная галька & 5 & 4,72 \\
\hline 7 & Кварцит песчаниковый & 1 & 0,94 \\
\hline 8 & Тальковый сланец & 1 & 0,94 \\
\hline 9 & Кость & $\mathbf{1 0 6}$ & 0,94 \\
\hline & \multicolumn{2}{|c|}{} \\
\hline
\end{tabular}

Таблица 2.

Объекты изображения зооморфной скульптуры малых форм. Анетовка 2

\begin{tabular}{|c|c|c|c|}
\hline № п/ா & Изображаемое животное & $\begin{array}{c}\text { К-во } \\
\text { изделий }\end{array}$ & $\%$ \\
\hline 1 & Мамонт & 59 & 55,7 \\
\hline 2 & Бизон & 19 & 17,9 \\
\hline 3 & Заяц & 5 & 4,7 \\
\hline 4 & Птица & 4 & 3,8 \\
\hline 5 & Животное семейства кошачьих & 4 & 3,8 \\
\hline 4 & Медведь & 3 & 2,8 \\
\hline 7 & Лошадь & 1 & 0,9 \\
\hline 8 & Носорог & 1 & 0,9 \\
\hline 9 & Зооморфы, сложно определимые & 4 & 3,8 \\
\hline 10 & Двойные фигурки, «перевертыши» & 6 & 5,7 \\
\hline & Итого & 106 & 100 \\
\hline
\end{tabular}



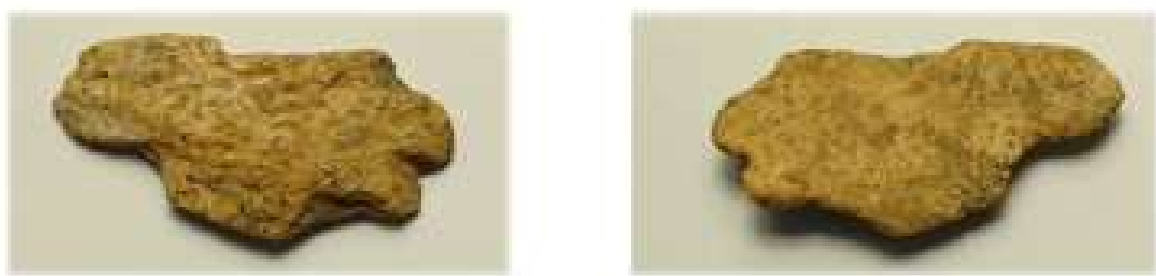

A

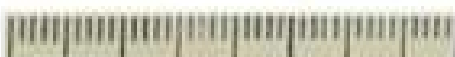
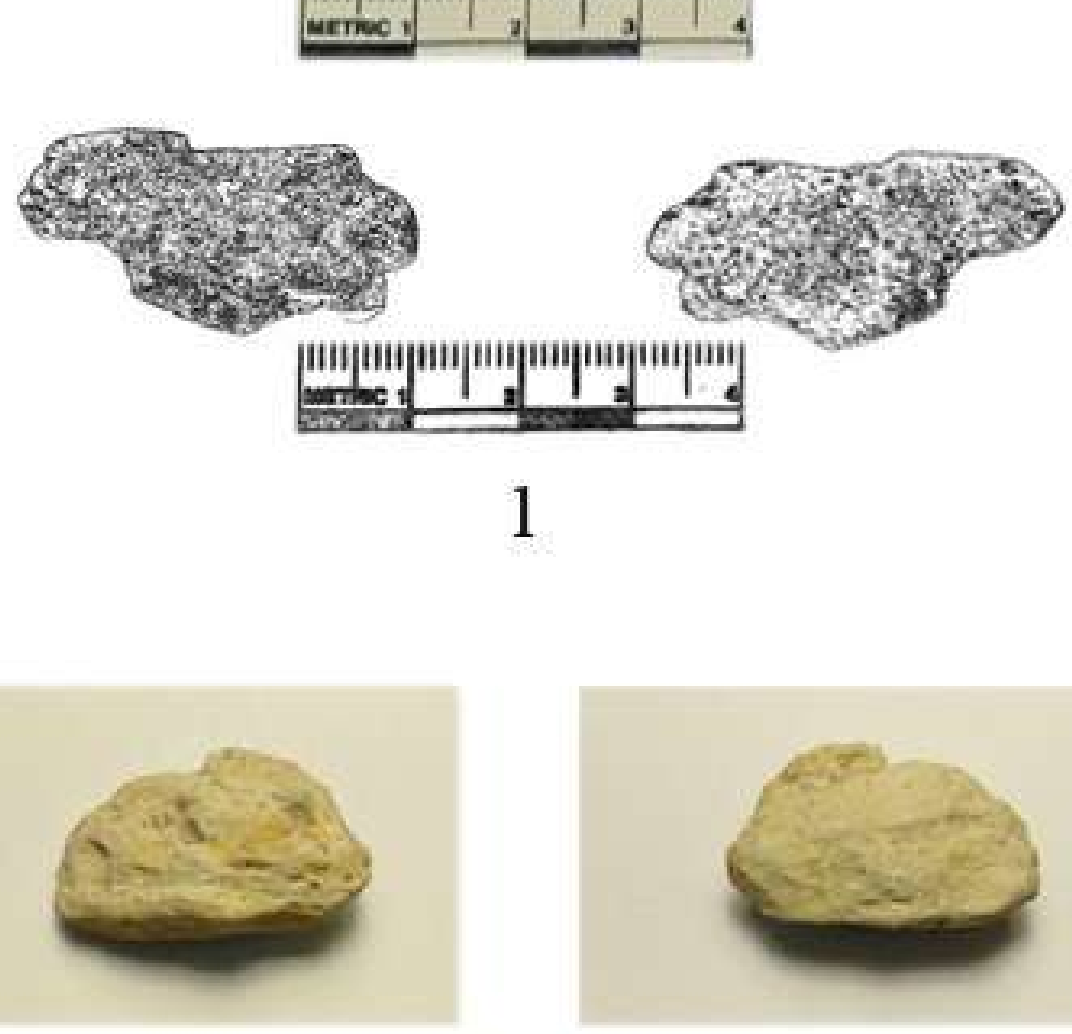

Б
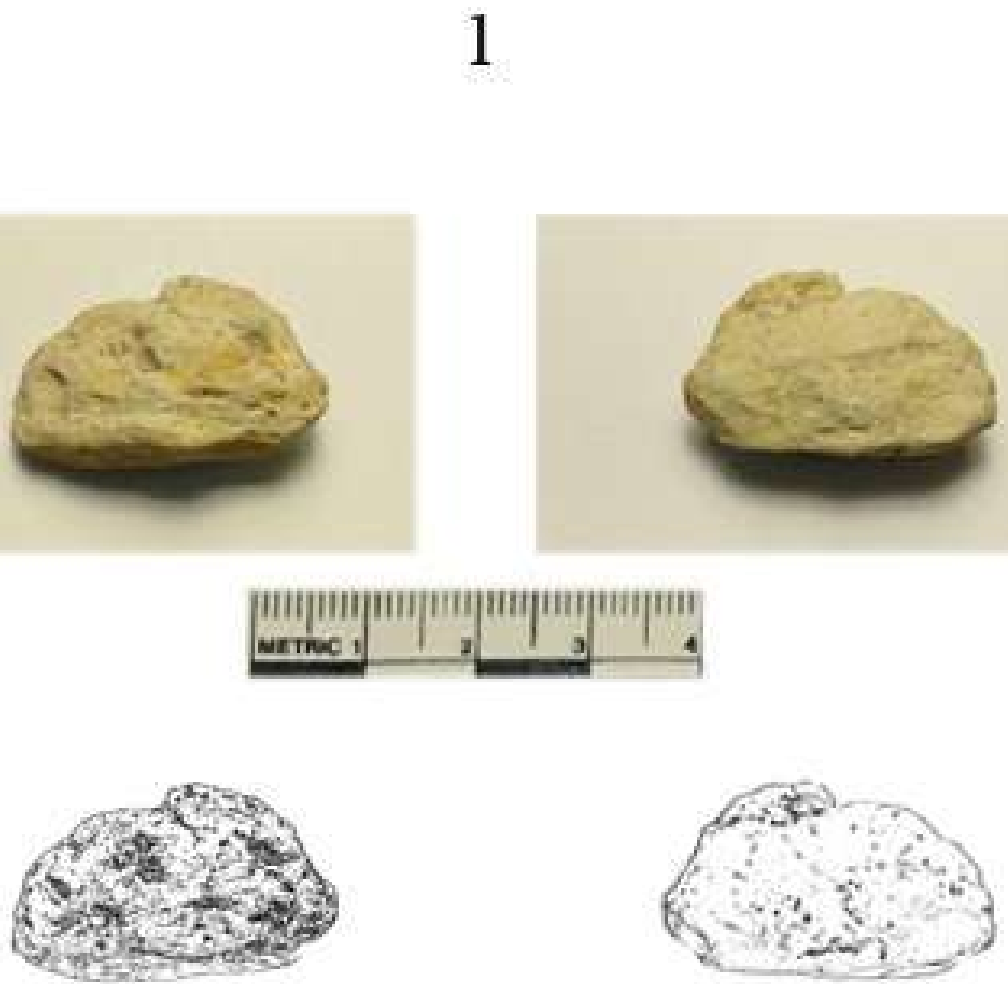

Б

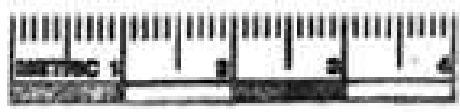

2

Рис. 1. Анетовка 2. Зооморфная скульптура малых форм.

1, 2 - фигурки зайцев (1 - кость, 2 - каолин). 

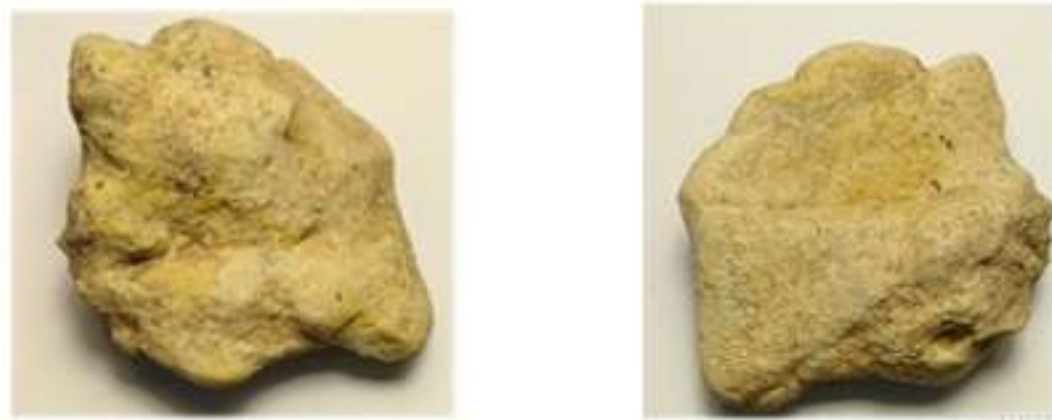

A
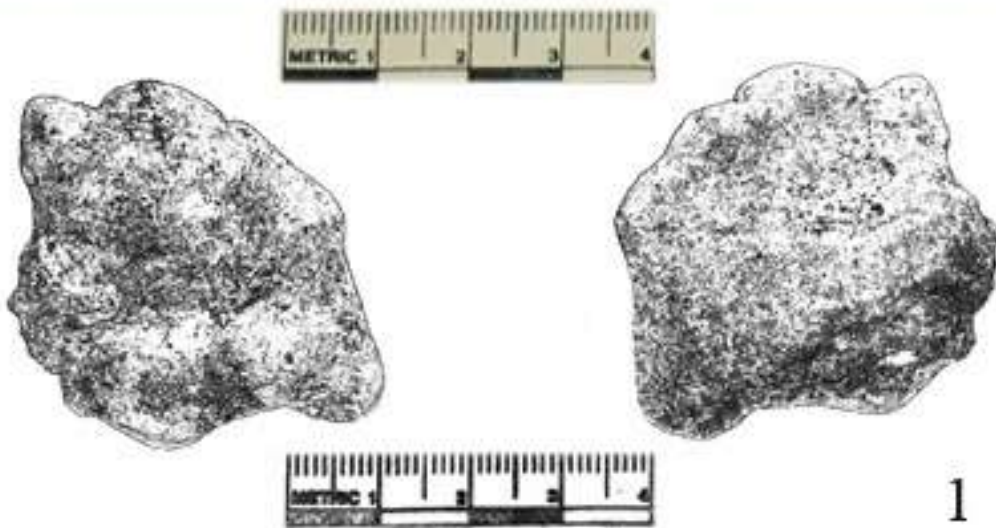

1
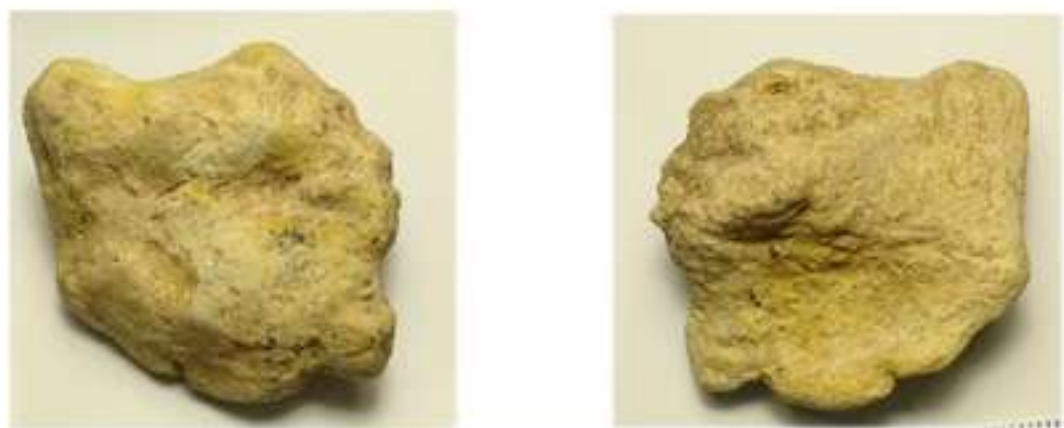

Б

A
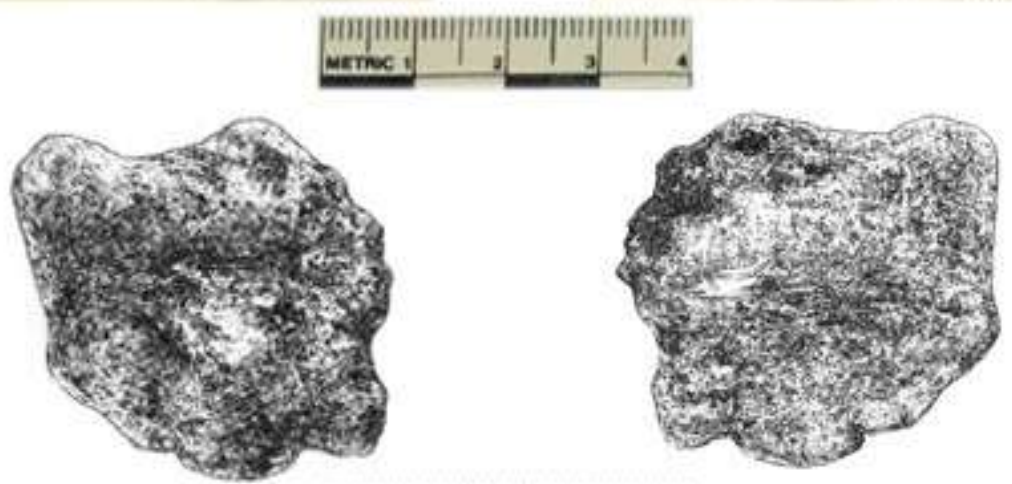

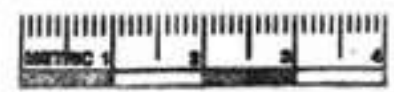

2

Б

Рис. 2. Анетовка 2. Зооморфная скульптура малых форм.

Двойное изображение («перевёртыш»): 1,2 - фигурки мамонтов (глинистое стяжение). 

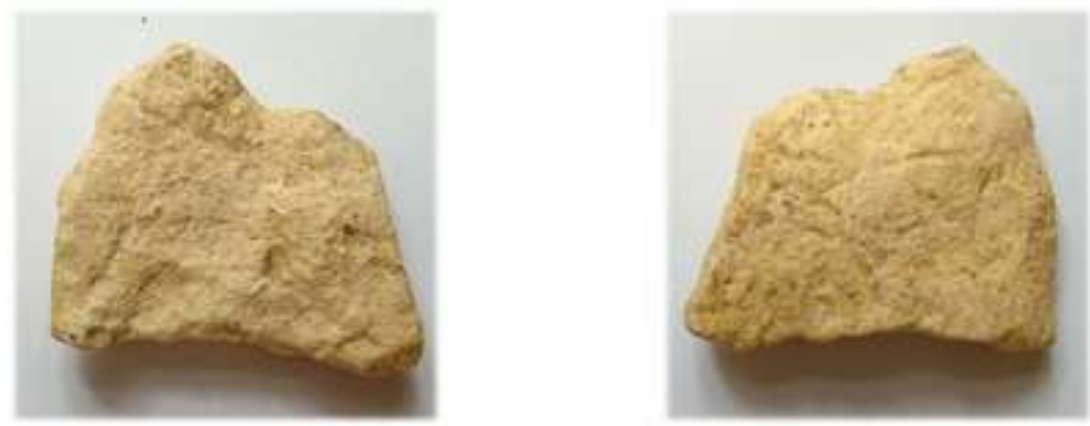

A
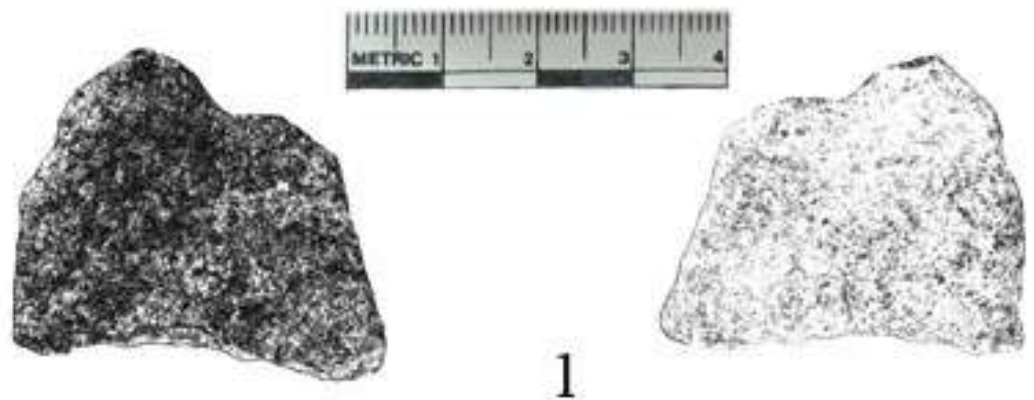

Б
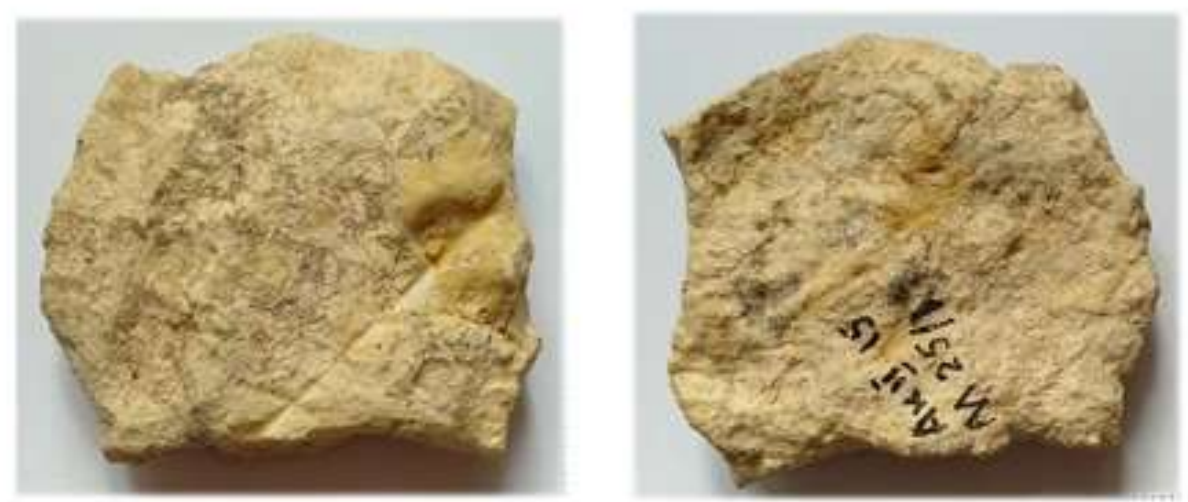

A

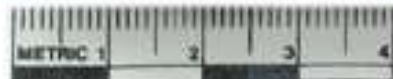
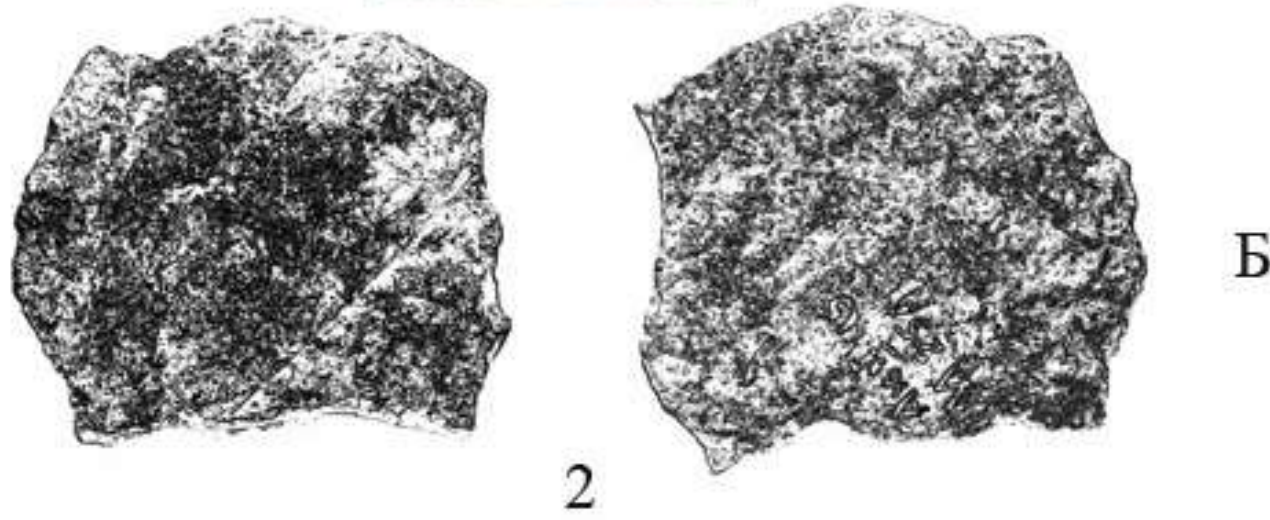

Рис. 3. Анетовка 2. Зооморфная скульптура малых форм.

1, 2 - фигурки мамонтов (глинистые стяжения). 

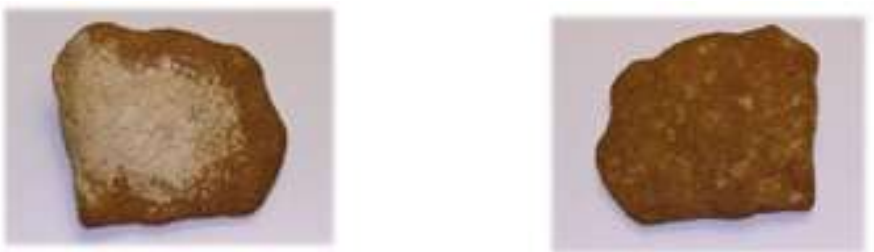

A

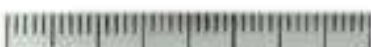

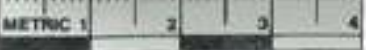
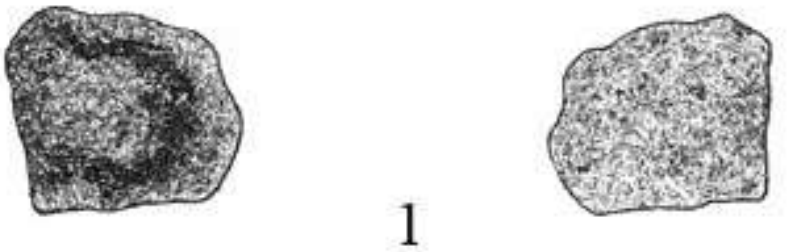

Б
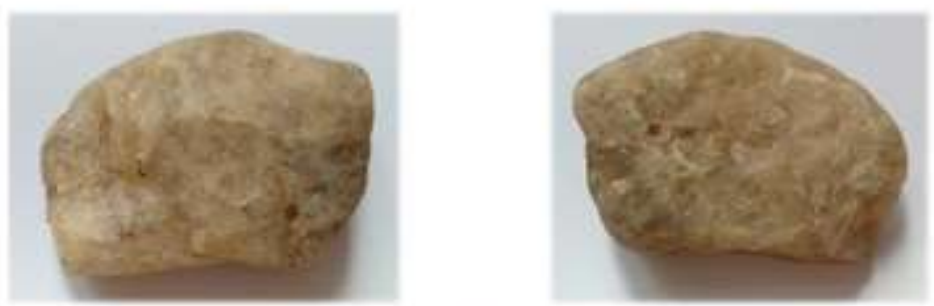

A

Б
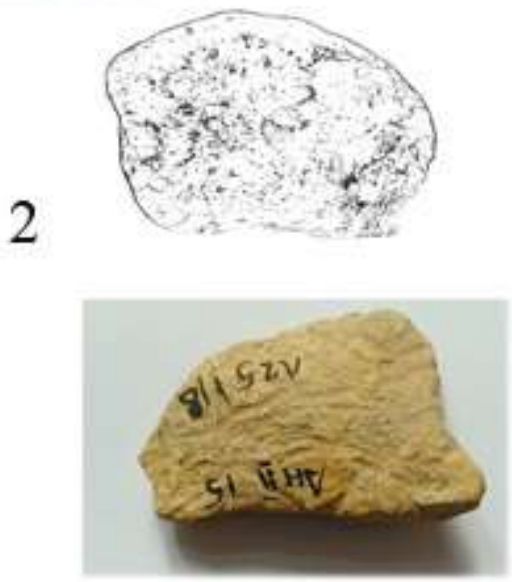

A
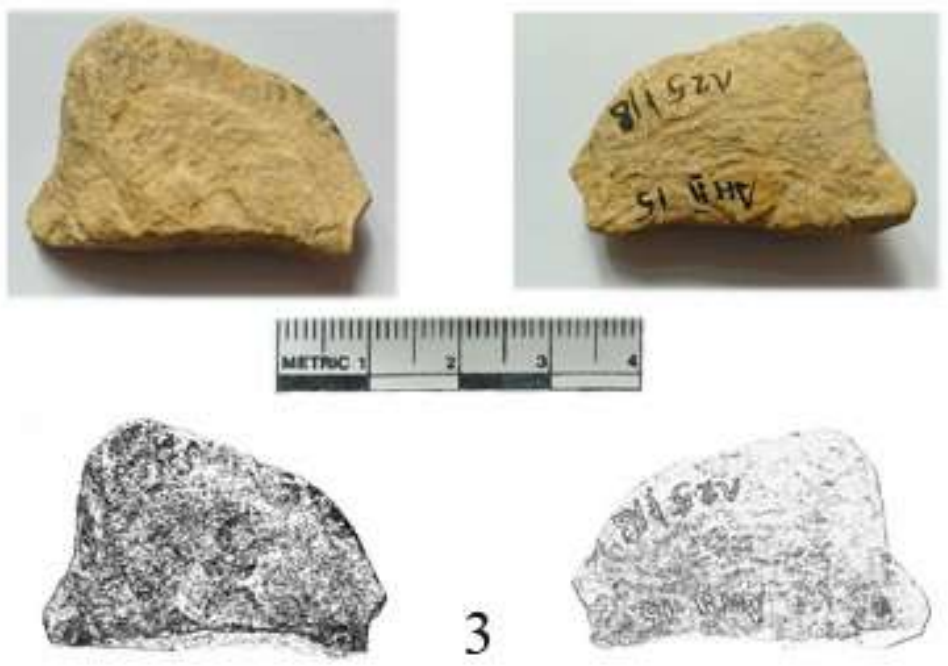

Б

Рис. 4. Анетовка 2. Зооморфная скульптура малых форм.

1, 2, 3 - фигурки мамонтов (1- охра, 2 - кварц жильный; 3 - глинистое стяжение). 

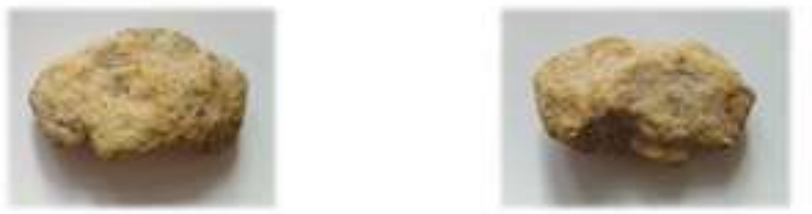

A
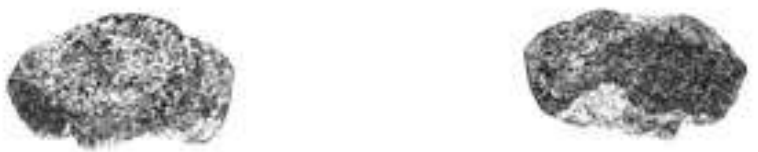

Б
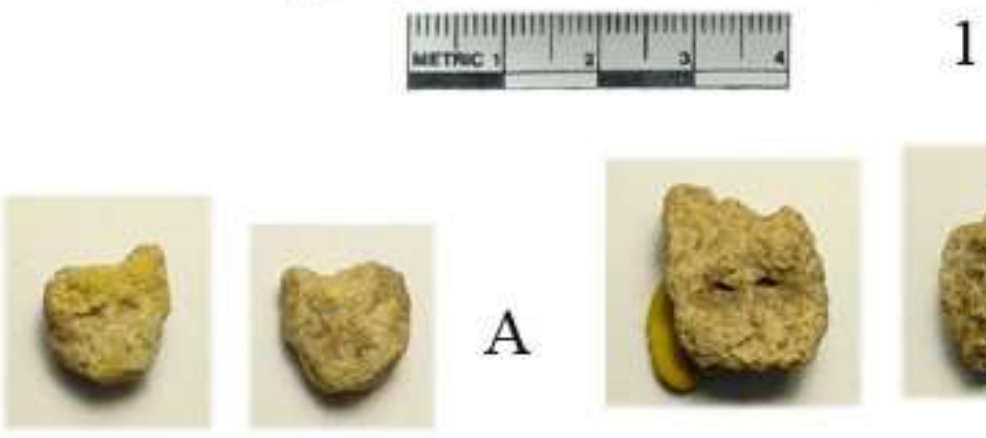

A
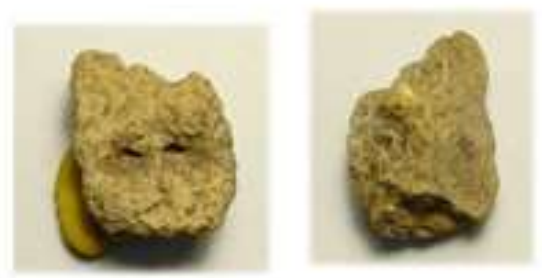

A
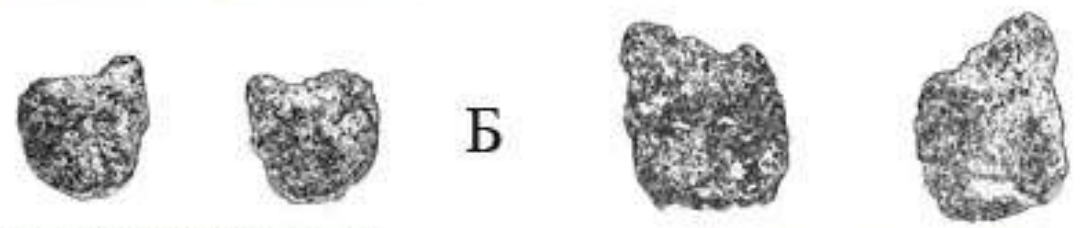

Б
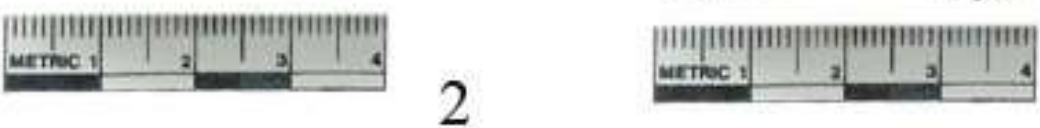

3
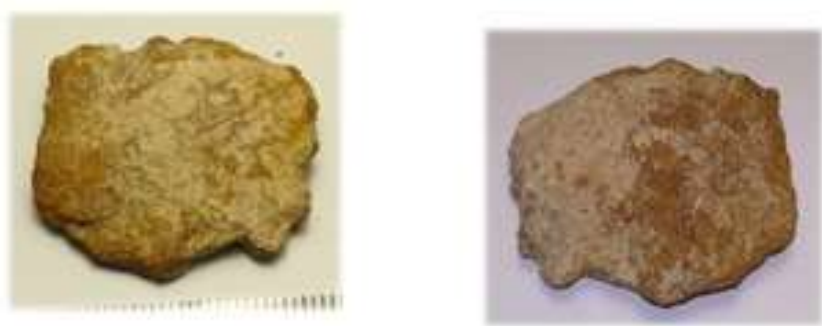

A
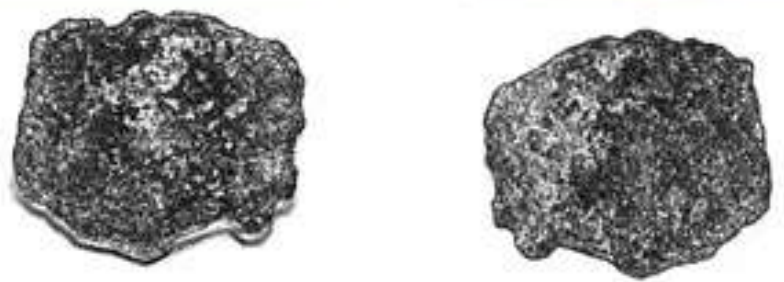

Б

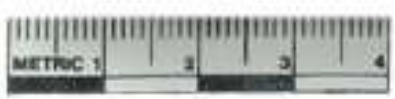

4

Рис. 5. Анетовка 2. Зооморфная скульптура малых форм.

1 - фигурка бизона; 2, 3 - изображения животных семейства кошачьих; 4 - фигурка бизона (1 2, 3 - глинистое стяжение, 4 - охра). 